\title{
原著 3
}

\section{痛風患者におけるタイプA行動パターンの検討}

\begin{tabular}{|c|c|c|c|c|}
\hline 寿 $^{1)}$ & 都外川 & 仙道 & 和子 ${ }^{1)}$ & 富田真佐子 ${ }^{2}$ \\
\hline 正一 & 山口 百子 ${ }^{4)}$ & 谷口 & 敦夫 ${ }^{1)}$ & 箱田 雅之 ${ }^{11}$ \\
\hline 千尋 ${ }^{1)}$ & 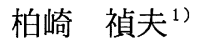 & 鎌谷 & 直之 ${ }^{1)}$ & \\
\hline
\end{tabular}

\section{要 約}

痛風や血清尿酸值と知能, 人格, 社会的行動性 などに関連があることは古くから指摘されてきた。 我々は, 痛風患者160名之対照群120名を対象にア ンケートを実施して痛風におけるタイプA行動パ ターンの関与を検討した，その結果，A型傾向判 定表にもとづくタイプAスコアの平均は, 痛風群

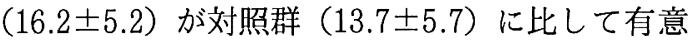
に高く $(\mathrm{P}<0.0001), 17$ 点をカットオフ点として タイプA行動パターンを有する頻度を比較しても 痛風群 (43.8\%) が対照群 (28.3\%) より多く (Odds ratio 1.97, $\mathrm{P}<0.01$ ), 特に「いつも忙し い生活をしている」，「仕事その他のことで，他 人と競争するという気持を持ちやすい」という 2 項目が痛風群で有意に多かった。しかし，タイプ A 項目より食事量, 食事の早さ, 飲酒習慣などは の生活パターンの項目の方が痛風群に集積してい ることあ示され, タイプA行動パターンを持つ個 人は尿酸值を上昇させる生活パターンをとる可能 性が高く, その個人の行動の結果として間接的に 痛風の発症を促進していると考えられた. タイプ $\mathrm{A}$ 行動パターンの修正を目的とした生活指導は, 痛風患者の良好なコントロールと予後の改善のた めにあ重要であると考えられた。

\section{緒言}

痛風や血清尿酸值と知能, 人格, 社会的行動性 などの関連については従来より多くの疫学的検討 が行われてきた。 その研究の歴史は古く，すでに 紀元前 2 世紀に痛風発作と情動的要因との関連が 指摘されている (1). 以後, 血清尿酸值と知能, 学習成績, 社会階級, 性格, 気質などとの関係を 論じた報告が数多くなされ，今日我々が痛風患者 と接して実感している性格, 生活習慣, 社会的行 動などは, 長い歴史の中で統計的に裏付けられた 科学的事実となってきた，血清尿酸值と社会階級 に関する報告は，1778年の報告を初めとし（2）， 同一事業所内において管理者は現場労働者より血 清尿酸值が有意に高い（3）, 企業管理職を調べ 上流企業の方が中流企業より尿酸值が高い（4） など, 社会階級と血清尿酸值はある程度正の相関 を示すという報告が多い，また知能や学習成績に 関しては，軍隊における知能テストと血清尿酸值 が弱い相関を示したという報告（ 5 ），高校生に おいて, 血清尿酸值が知能とは相関しないが，学 業成績とは相関がみられたとするもの（6）など がある。これらの事実からは痛風患者ないしは血 清尿酸值之社会的な向上心, やる気などと関連す ると考えられており（1），一定の行動パターン との関連が考えられている。
受付 : 1997年 1 月 20 日, 受理 : 1999年 4 月 8 日

1）東京女子医科大学附属膠原病リウマチ痛風センター

2) JR東日本中央保健管理所

3）東京都立老人総合研究所情報シュミレーション部門

4 ）国立健康・栄養研究所・成人健康・栄養部
Hisashi Yamanaka, Shin Totokawa, Wako Sendo, Atsuo Taniguchi, Masayuki Hakoda, Chihiro Terai, Sadao Kashiwazaki and Naoyuki Kamatani

Masako Tomita

Shoichi Mizuno

Momoko Yamaguchi 

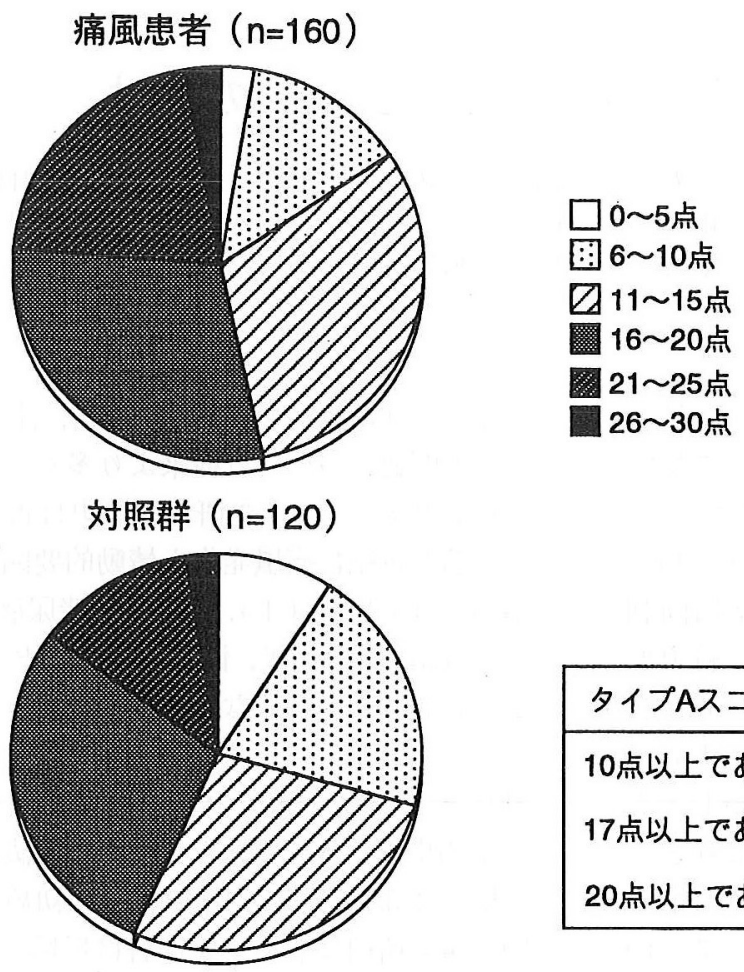

図 1 : 痛風群と対照群のタイプAスコア

図の右に示すコラムのようにタイプAスコアを 5 点毎に分類し，円グラフ表示した.

一方，高尿酸血症は虚血性心疾患の危険因子之 して知られており，また痛風患者の死因として虚 血性心疾患をはじめとする動脈硬化性疾患が注目 されている. 虚血性心疾患患者には攻撃的，競争 心が強い，短気，目標達成への執着が強いなどの 行動パターンが存在することが知られ, タイプ A 之呼ばれている $(7,8)$.今回我々は, 痛風，虚 血性心疾患, 一定の社会的行動様式の 3 つを関連 づけるものとしてタイプA行動パターンに着目し, 検討を加えた。

\section{対象および方法}

対象 : 痛風群は東京女子医大膠原病リウマチ痛風 センター外来にて加療中の原発性痛風患者の中か ら無作為に抽出した 20 代〜 50代の男性のみ 160 例. 対照群は首都圏に勤務する職域集団の成人男性で
20 代 50 代の各年代各々 30 名，合計 120 例である. 各群の年令は痛風群 $44.7 \pm 8.4$ 歳 $($ mean $\pm \mathrm{SD}$, 以 下同様), 対照群 $39.2 \pm 10.2$ 歳で, 痛風群が有意に 高かった（P<0.001）。これは対象群では各年代3 0名を抽出したのに対し, 痛風群では無作為抽出 になったためであり，痛風群では20代の患者が少 なかった。

方法 : アンケート方式にて実施した。痛風群は 外来受㟝時にアンケートを手渡し，即日回収した． 対照群も健康診断時にアンケートを手渡し，即日 回収した。アンケートは前田らの「A型傾向判定 表」に基づく12項目（9）之, 被験者の生活パター ンや周辺情報を得るための 8 項目（生活パターン 項目）の合計20項目の簡便なものを作成し，使用 した（表 1).

$\mathrm{A}$ 型傾向判定表の点数の解析は前田らの原法に 
表 1 アンケート用紙の内容

\begin{tabular}{|c|c|c|c|}
\hline 該当するところにO印をつけてくたさい。 & \begin{tabular}{|c|} 
いつも \\
そうである
\end{tabular} & $\begin{array}{l}\text { しはしは } \\
\text { そうである }\end{array}$ & $\begin{array}{c}\text { Zんなこと } \\
\text { はない }\end{array}$ \\
\hline 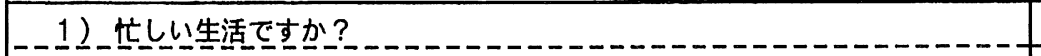 & & & \\
\hline 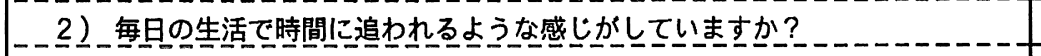 & & & \\
\hline 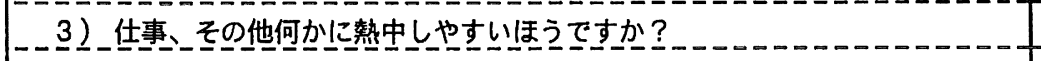 & & & \\
\hline 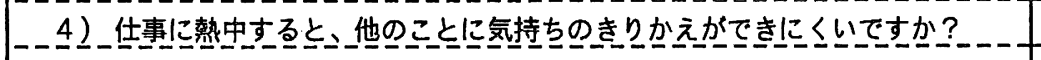 & & & \\
\hline 5) やる些上はかなり噋底的にやらないと気がすまない方ですか？ & & & \\
\hline 6) 自分の仕事也行動占自倶がもてますか? & & & \\
\hline 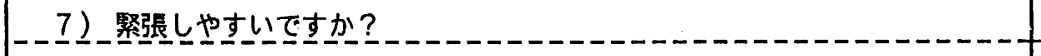 & & & \\
\hline 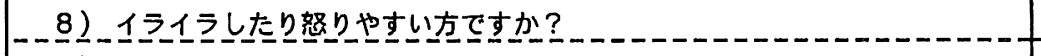 & & & \\
\hline 9)_きさよ之面ですが? & & & \\
\hline 10２＿腾気な方ですか？ & & & \\
\hline 112＿気性がはば゚しいですかか? & & & \\
\hline 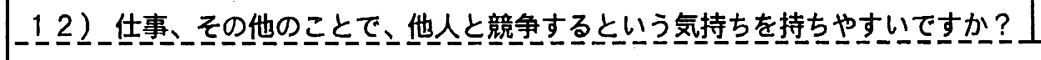 & & & \\
\hline & はい & いいえ & わからない \\
\hline -13）_-回の食事量は多い|玉うですか（大食傾向がありますか）？ & & & \\
\hline 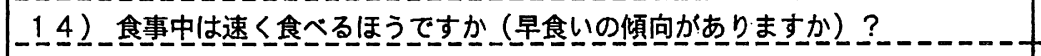 & & & \\
\hline 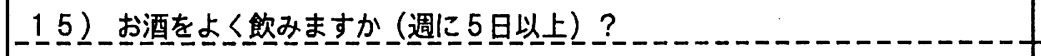 & & & \\
\hline 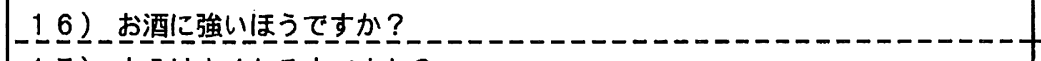 & & & \\
\hline 17)－水分は上_と方方ですか？ & & & \\
\hline 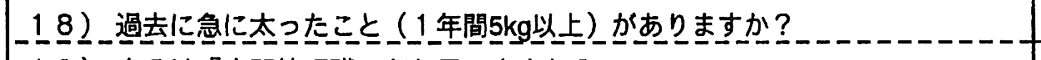 & & & \\
\hline 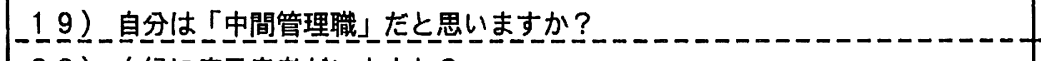 & & & \\
\hline 20）血縁に痛風患者がいますか？ & & & \\
\hline
\end{tabular}

表 2 両群の背景

\begin{tabular}{|c|c|c|c|c|c|c|c|}
\hline & & & 痛風群 & & & 対照群 & \\
\hline & & $n$ & mean & SD & $\mathrm{n}$ & mean & \\
\hline \multirow[t]{3}{*}{ 体格 } & 身長 & 154 & \multicolumn{2}{|c|}{$169.3 \pm 6.1$} & 96 & $169.1 \pm 6.3$ & ns \\
\hline & 体重 & 157 & \multicolumn{2}{|c|}{$71.4 \pm 14.1$} & 96 & $67.8 \pm 9.9$ & $P<0.05$ \\
\hline & $\mathrm{BMI}$ & 154 & \multicolumn{2}{|c|}{$24.9 \pm 4.8$} & 93 & $23.8 \pm 3.8$ & $P<0.05$ \\
\hline \multirow[t]{5}{*}{ 㭘査値 } & UA & 157 & \multicolumn{2}{|c|}{$6.4 \pm 1.5$} & 120 & $5.8 \pm 1.3$ & $P<0.005$ \\
\hline & T-cho & 157 & \multicolumn{2}{|c|}{$204.1 \pm 47.5$} & 119 & $199.6 \pm 41.6$ & ns \\
\hline & TG & 157 & \multicolumn{2}{|c|}{$248.6 \pm 292.4$} & 120 & $190.4 \pm 256.4$ & ns \\
\hline & FBS & 135 & \multicolumn{2}{|c|}{$105.4 \pm 28.5$} & 120 & $101.8 \pm 24.8$ & ns \\
\hline & HDL-C & 156 & \multicolumn{2}{|c|}{$53.9 \pm 15.8$} & 78 & $49.2 \pm 15.4$ & $P<0.05$ \\
\hline 治療中の & 痛風 & 157 & \multicolumn{2}{|c|}{ 157例（100\%） } & 96 & 2 例 $(2.1 \%)$ & $P<0.0001$ \\
\hline \multirow[t]{2}{*}{ 疾患 } & 糖尿病 & 157 & \multicolumn{2}{|c|}{ 15例（8.8\%） } & 96 & 0 & $P<0.005$ \\
\hline & 高血圧 & 157 & \multicolumn{2}{|c|}{ 32例 $(20.4 \%)$} & 96 & 3 例 $(3.1 \%)$ & $P<0.0005$ \\
\hline
\end{tabular}


表 3 合併症で層別化した各スコア

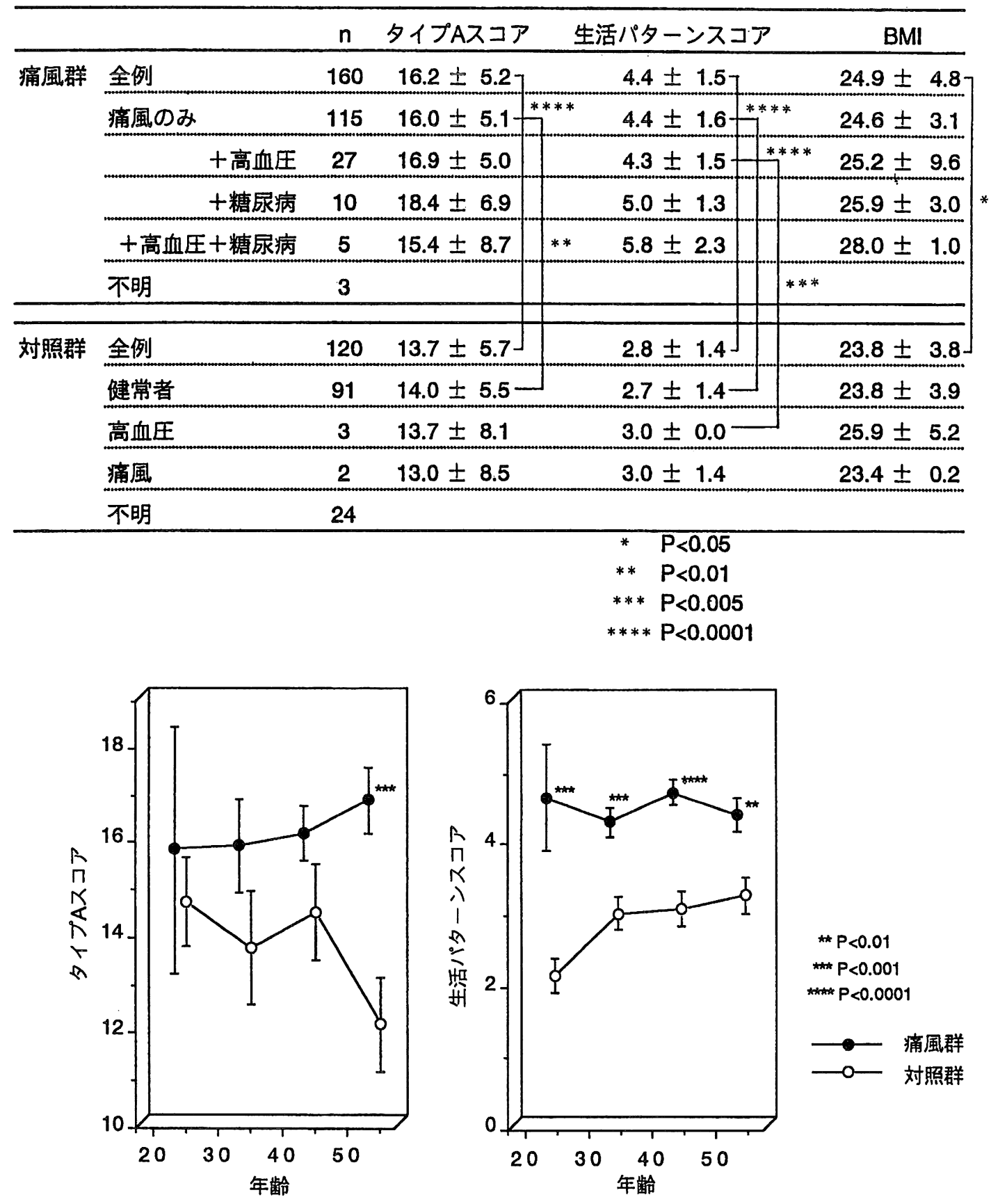

図 2 : タイプAスコアと生活パターンスコアの年代別変化

タイプAスコアと生活パターンスコアの年代別変化を痛風群 (-の-)，対照群 (一○一) で比 較し，両群間の有意を表示した. 
基づいた（9).すなわち質問 4，5，9の3 項目 は点数を 2 倍して計算し, 荷重合計をタイプ A ス コアとした。 そして点数が17点以上をタイプA行 動パターンを有すると判定した. 生活パターン項
目の合計は生活パターンスコアと暫定的に名づけ て検討した。統計解析には, t-test, $\chi^{2}$ test, Spearman's Rank Correlation を用いた.
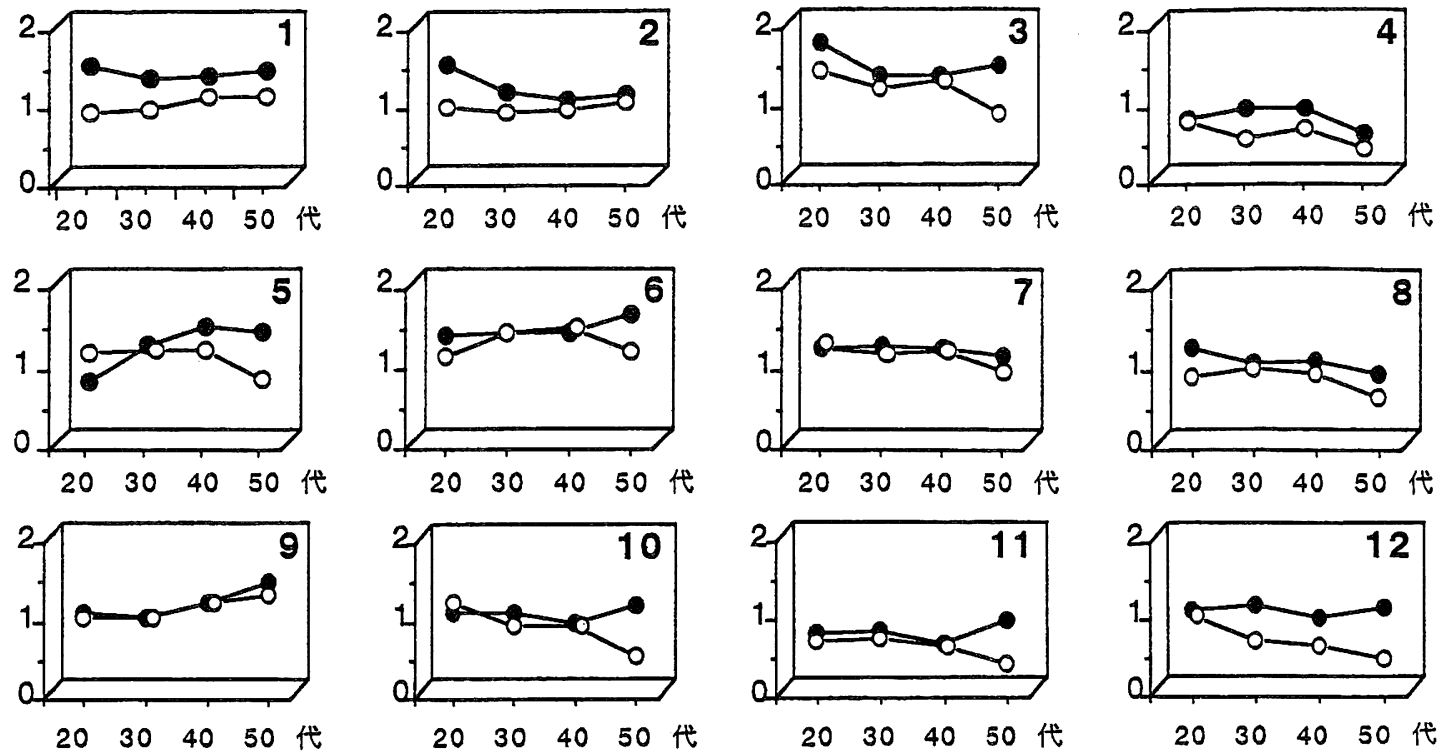

3-1 A 型判定項目
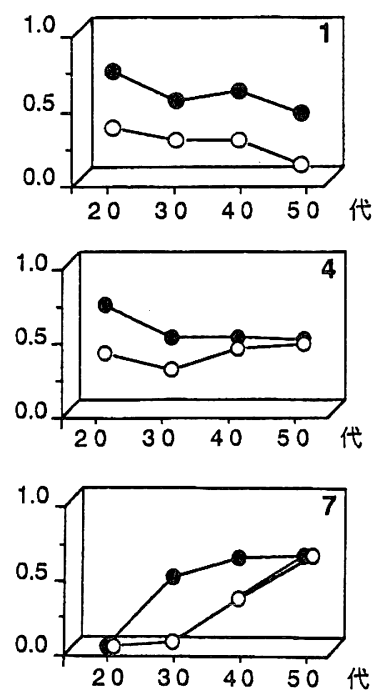
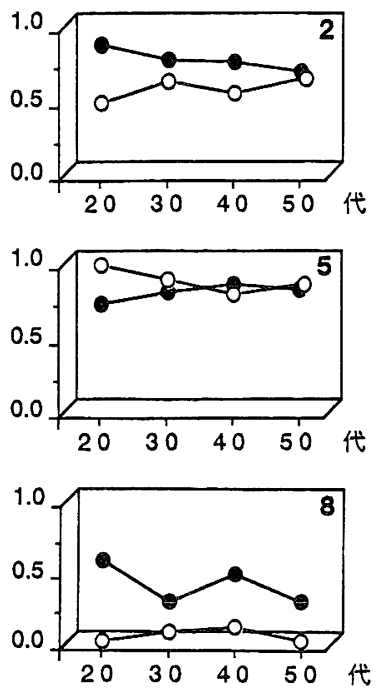
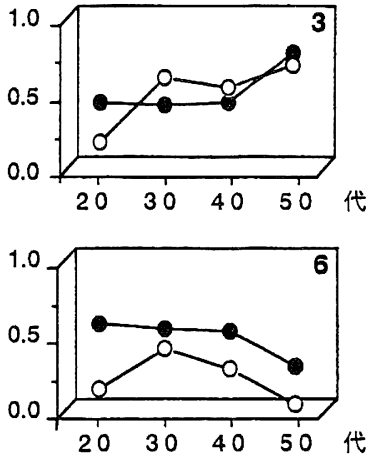

3-2 生活パターン項目を示す．各質問項目の痛風群（ーー，対照群（ー○ー）における 平均点数 (縦軸)を年代別に比較した.

図 3 : 各質問項目の年代別変化 


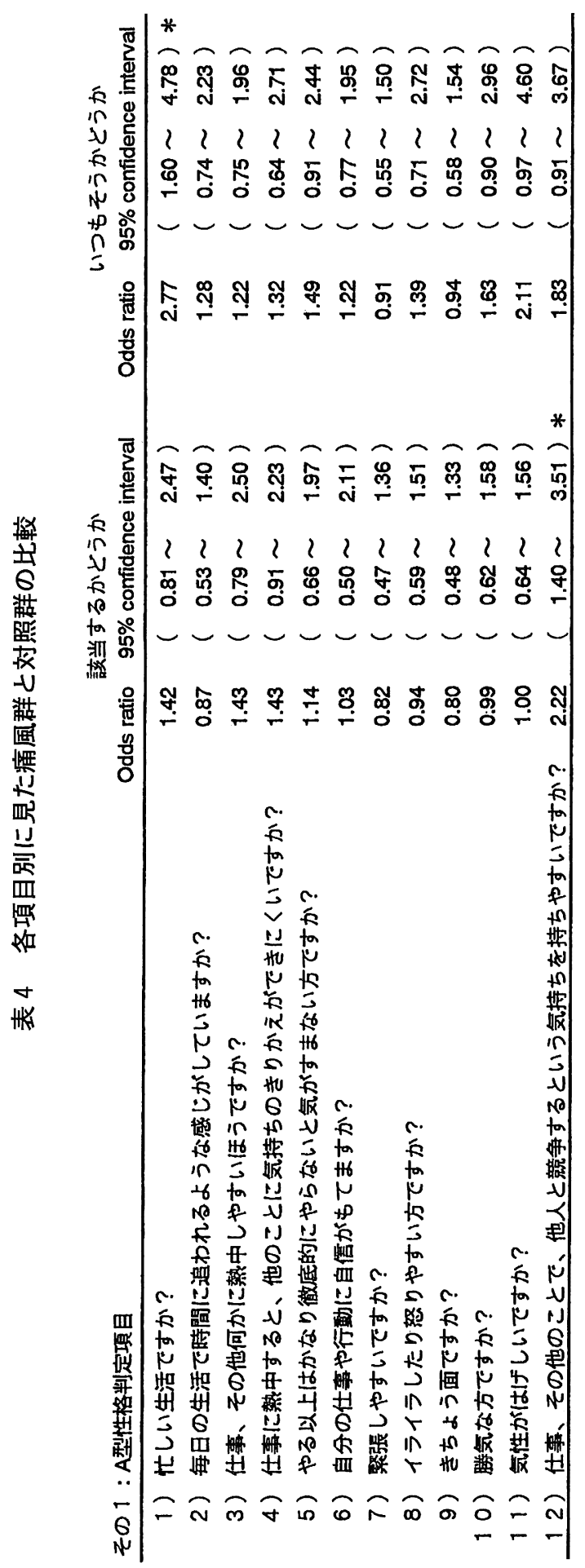

U.
$\dot{0}$
v
*
$*$

in

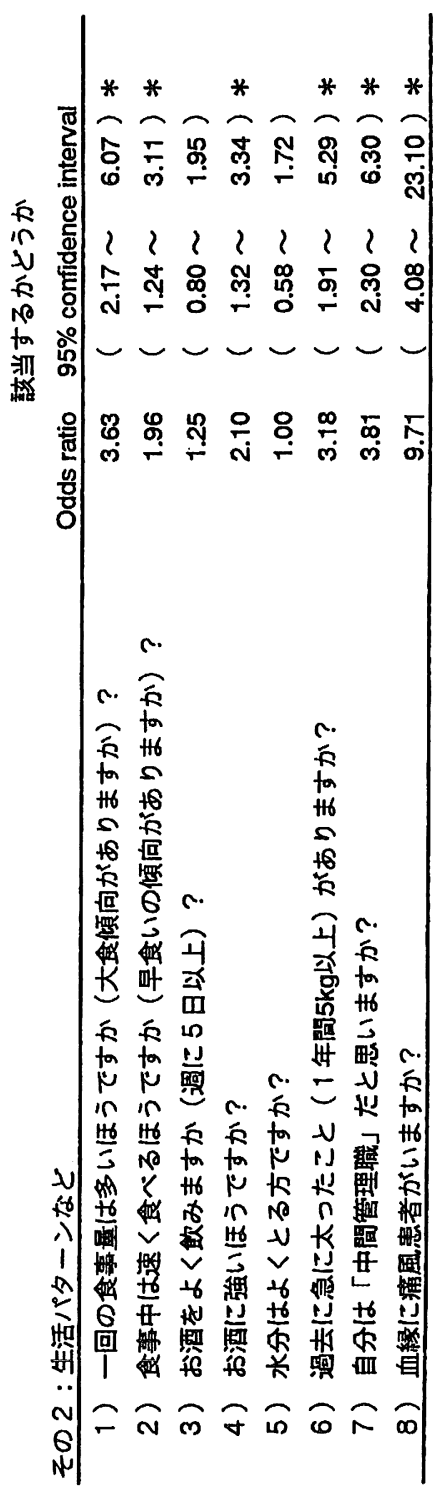


表 5 対照群における血清尿酸值と各項目の相関

その1：A型性格判定項目

Spearman's Rank Correlation

1) 忙しい生活ですか?

$P<0.05$

2）毎日の生活で時間に追われるような感じがしていますか？

n.s.

3）仕事、その他何かに熱中しやすいほうですか?

n.s.

4）仕事に熱中すると、他のことに気持ちのきりかえができにくいですか？ $\quad P<0.01$

5) やる以上はかなり徹底的にやらないと気がすまない方ですか？ n.s.

6) 自分の仕事や行動に自信がもてますか?

n.s.

7) 緊張しやすいですか?

n.s.

8）イライラしたり怒りやすい方ですか？

$\mathrm{P}<0.05$

9) きちよう面ですか?

n.s.

10）勝気な方ですか?

n.s.

11) 気性がはげしいですか?

$P<0.05$

12 ) 仕事、その他のことで、他人と競争するという気持ちを持ちやすいですか? n.s. タイプAスコア合計（上記荷重合計）

n.s.

その 2 : 生活パターン

1）一回の食事量は多いほうですか（大食傾向がありますか）？

2）食事中は速く食べるほうですか（早食いの傾向がありますか？

$\mathrm{P}<0.05$

3）お酒をよく飲みますか（週に5日以上)？ n.s.

4) お酒に強いほうですか?

n.s.

5) 水分はよくとる方ですか?

n.s.

6) 過去に急に太ったこと(1年間5kg以上)がありますか？

n.s.

7）自分は「中間管理職」だと思いますか?

$P<0.01$

8)血縁に痛風患者がいますか？

$P<0.05$

生活パターンスコア合計

$P<0.01$

n.s.

\section{n.s.: not significant}

\section{結 果}

痛風群と対照群の背景を表 2 に示す。体格的に は痛風群の方が体重, Body Mass Index (BMI) が 大きかったが, 総コレステロール, 中性脂肪, 空 腹時血糖などには差は認めなかった，また治療中 の合併症は痛風群の方が有意に多かったため, こ れらの合併症によるバイアスが懸念された。そこ で, 痛風群, 対照群共に合併症で層別化し, 夕イ プAスコア, 生活パターン項目を検討した（表 3) が, 層別化した各群内では夕イプAスコア, 生活 パターン項目やBMIには有意の差を認めなかった。 そこで, 以後の検討は, 合併症を有する症例す解
析対象に加え，痛風群160例，対照群120例におい て実施した。

A 型傾向判定表にもとづくタイプAスコアの平 均は, 痛風群 $16.2 \pm 5.2$, 対照群 $13.7 \pm 5.7$ で痛風群 が有意に高かった（P<0.0001，表 3$)$. 前田の原 法に基づき点数が17点をカットオフ点としてタイ プA行動パターンを有するとすると，その頻度は 痛風群 (43.8\%)，対照群 (28.3\%) で痛風群が有 意に多かった (Odds ratio 1.97, $\mathrm{P}<0.01$ ).こ のカットオフ点を 10 点, 20 点でも検討したが，い ずれの点においても点数の高い群で有意に痛風群 が多かった（図 1).一方, 生活パ夕ーン項目で 
は, 合計スコアが痛風群 $4.4 \pm 1.5$, 対照群 $2.8 \pm 1.4$ で痛風群が有意に高かった（P<0.0001）が，そ の差はタイプAスコアよりあ著明であった。

アンケートの各項目について痛風群と対照群で 比較を行った．「A型傾向判定表」に基づく12項 目は，いつもそうである，しばしばそうである， そんなことはない，の 3 段階の回答になっている ため，前 2 回答のいずれかを答えた場合を「該当 する」, いつあそうであると答えた場合は「いつ あそうである」と判定し, 両群間のOdds比を算 出した（表 2-1）。の結果，「いつも忙しい生 活をしている」,「仕事その他のことで, 他人と 競争するという気持を持ちやすい」という 2 項目 が痛風群で有意に多かった。一方, 生活パターン 項目の検討では, 痛風の家族歴が痛風群で多かっ たのは当然としても, 他の 7 項目中 5 項目までが 痛風群が有意に多いという結果であった.

次に, タイプAスコアと生活パターンスコアの 年代別の変化を検討した (図 2 ). タイプAスコ アは加齢と共に痛風群ではやや上昇, 対照群では やや下降傾向が見られ，50歳代で有意差が見られ た. 一方, 生活パターンスコアの検討では, 痛風 群は若年時から高值で経年的に变化しなかったの に比して対照群では加秢と共に増加する傾向があっ たが，スコアは各年代で有意に痛風群が高かった．

そこで，各質問項目別に年代による変化を検討 したのが図 3 である.まず，タイプAスコアの成 分では, 各質問の平均点数は痛風群, 対照群共に ほぼ並行して推移する様子がわかる，ただ，Q3， Q6，Q10，Q11，Q12などは50代になって乘離が 認められた，ところが，生活パターンスコアの成 分では, タイプAスコアの成分とは逆にほとんど の質問で20代，30代などの若い年代での乘離が認 められた. 中間管理職であるとする項目は両群と あに年代別に増加しているが，痛風群の方が上昇 が早かった.

次に, タイプAスコアと生活パターンスコアの 関連を検討した，痛風群と対照群の合計 160 名を タイプAスコアで分け, 各群の生活パターンスコ アの平均を図 4 に示す. 全体にタイプAスコアが 上昇すると共に生活パターンスコアが高くなる傾
向が見られ，タイプAスコアが 5 点以下の群はそ れ以上の群より生活パターンスコアが有意に低かっ た.

さらに，血清尿酸值におよぼすこれら各項目の 影響を検討した。痛風群はほとんどの症例が薬物 治療中であり, 固有の血清尿酸值を求めることが できなかったため, 対照群における血清尿酸值と タイプAスコア, 生活パターンスコアの関連を検 討した (表 5 ). その結果, タイプAスコア, 生活 パターンスコアを構成するいくつかの項目が血清 尿酸值と有意に相関することが示された.

\section{考 察}

痛風には虚血性心疾患が高率に合併することが 指摘されている. かっては痛風患者の死因のなか で圧倒的に多かった痛風腎による腎不全が高尿酸 血症に対する治療学の進歩に伴い激減した現在で は，虚血性心疾患は悪性新生物に次ぐ死因の第 2 位となっている(10). 血清尿酸值と虚血性心疾 患の発生率が正の相関を示すという報告すあり (11)，高尿酸血症は虚血性心疾患のリスクファク ターの一つと考えられている。この両疾患の関連 は高血圧, 高脂血症, 肥満などのクラスターを介 すむのや, 尿酸塩そのものによる血管内皮障害, 血小板機能異常など様々な機序が推測されている （12）が，定説はない.

一方, タイプA行動パターンは米国の循環器医 であるFriedman, Rosenmanらによって虚血性心 疾患患者に見られる特有の行動様式として提唱さ れたもので, 現在では虚血性心疾患のリスクファ クターと考えられている（7）。タイプA行動パ ターンでは安静時の血圧, カテコールアミン值は タイプ B と差異は認められないむのの，心理的・ 物理的ストレスを受けた時の交感神経系の反応性 が高いことが証明されている。すなわち，度重な るストレスに対する過剩反応が血圧上昇, 心拍数 増加，心刺激伝導障害をひきおこし，虚血性心疾 患の発症につながるというもので，虚血性心疾患 のハイリスク群であることが以前から疫学的に立 証されている $(13,14)$ うえに，虚血性疾患以外 に扔いても疾患の発症素地になることが示されて 
いる(15).タイプA行動パターンの特徴を要約 すると時間的焦燥感を持って精力的に行動し，他 者への競争意識が強いものである. 痛風患者に見 られる特有の行動パターンがタイプA行動パター ンとよく似ていることから, 痛風に虚血性心疾患 が多いことを説明するひとつの候補としてこの夕 イプA行動パターンに注目し, 痛風患者における 頻度を検討した。本研究は，対照群は首都圈に勤 務する職域集団の成人男性を対照群として用いた ために，通院中の患者群との整合性の上でいくつ かの問題があった. まず, 患者群は複数の職種に またがるが，対照群は単一企業体の勤務者である こと, 痛風以外の疾患にて治療中の者の頻度が異 なることなどである. 前者の比較を完全に行うと なれば, 同一職種における健常者と痛風患者を比 較する必要がある. 対照群120例中には治療中の 痛風患者が存在していたが，わずか 2 名で解析不 能であった. しかし，後者については層別化分析 により合併の有無がスコアに影響を及ぼさないこ とが明かになったため, バイアスとはならないと 考えられた。

このような条件下で解析したかぎりにおいては， 痛風群ではタイプ $\mathrm{A}$ スコアが高く, タイプ $\mathrm{A}$ 行動 パターンと分類しうる患者が対照群に比して多かっ たが, 痛風群におけるタイプAの頻度は半数以下 に留まった．このことから，タイプ行動パターン は痛風発症の原因であるとは言えないが，少なく とあ痛風患者の病態形成に関連を有すると考えら れる。

また, 痛風群の患者はほとんどの例が薬物治療 中であり, 血清尿酸值む対照群と差はあるむのの かなり低下している（表 2 ）ことから, 高尿酸血 症がタイプA行動パターンの原因ではなく, タイ プA行動パターンが高尿酸血症を誘発するひとつ の原因となっていることが推測される.タイプA 行動パターンの各項目を詳細に検討すると, 忙し い生活, 競争心を持ちやすいなどの項目が対照群 とくらべ有意に多い傾向がみられ, 痛風患者は多 忙な生活をし，仕事に熱中しやすく，競争に富む といった現代社会の中でストレスの多い生活がう かがわれた．さらに，対照群においてこれらの各
質問項目と血清尿酸值との相関を検討すると, 痛 風群により多く認められる質問項目のいくつかが 血清尿酸值との関連を持つことが示された。この ことは生来の気質に加えて社会的因子が深く関与 しているあのと思われる.

興味深いことは, タイプA 項目より生活パター ン項目の方が痛風患者と対照群の差が大きかった ことである.しかも，タイプAスコアの高い群で は生活パターンスコアあ高くなる傾向も認められ た.タイプAなどの行動パターンは, 個人の現実 の行動を間接的に表現する手段であるのに対し， 生活パターンの項目としてあげた食事量, 食事の 早さ，飲酒習慣などは個人の行動そのものである. しかも,これらの行動は血清尿酸值を上昇させる ことが明かにされて抢り $(16,17)$ ，生活パター ンの方が痛風と強い関連を持っていることは理論 的にも納得できる。これらの結果からは，タイプ $\mathrm{A}$ 行動パターンを持つ個人は尿酸值を上昇させる 生活パターンをとる可能性が高く，その個人の行 動の結果として間接的に痛風の発症を促進してい ると考えられた。

行動パターンは, 複数の構成要素から成ってお り，体質・気質・性格といった先天的要素に，仕 事に追われるといった外的ストレスやライフス夕 イルなどの後天的な, 変容しうる環境要素が加わっ て形成される（18）。この意味で行動パターンは 性格のような固定的で変化しないものと異なり， 修正可能であるとされる. タイプA行動パターン を示す一群は，倦怠感や眠気といったストレスに 対する心身反応を認知できず, さらに仕事にのめ り込んでゅく傾向が強い（19，20）.したがって, この心身反応を患者自身に認識させ，タイプ A 行 動パターンが虚血性心疾患を起こす危険があるこ とを説明し，理解させる必要がある.

痛風患者に括いて夕イプA行動パターンの修正 を目的とした生活指導を行うことは，虚血性心疾 患などの重篤な合併症の発症を予防することだけ でなく，ストレスによる血清尿酸值の上昇を防止 する可能性むあり，きわめて重要であると考える. 今後, 痛風患者のタイプAを是正することにより 虚血性心疾患に対するリスクが減少するか否かに 
ついても検討を要すると考えられる.

本論文の一部は第28回日本プリン・ピリミジン 代謝学会総会において発表した.

\section{文献}

1 ）浅香昭雄: 血中尿酸值と性格 - 知能 高尿酸 血症と痛風 $1: 57-64,1993$.

2) Katz JL, Weiner H : Psychosomatic consideration in hyperuricemia and gout. Psychosom Med XXX 2 : 165-182, 1972.

3 ) Dunn JP, Brooks GW, Rodnan GP : Social class gradient of serum uric acid levels in males. JAMA $185:$ 431-436, 1963.

4) Anumonye A, Dobson JW, Oppenheim $S$, et al. : Plasma uric acid concentration among Edinburgh business executives. JAMA 208 : 1141-1144, 1969.

5 ) Stetten De W, Hearson JZ: Intellectual level measured by army classification battery and serum uric acid concentration. Science $129:$ 1737, 1959.

6 ) Kasl SV, Brooks GW, Rodgers WL : Serum uric acid and cholesterol in achievement behavior and motivation. JAMA 213 : 1292-1299, 1970.

7) Friedman M, Rosenman RH : Association of specific overt behavior pattern with blood and cardiovascular findings. JAMA 169 : 1286-1296, 1959.

8) Friedman M, Ghandour G: Medical diagnosis of type A behavior. Am Heart $\mathrm{J}$ 126: 607-618, 1993.

9）前田 聰：行動パターン評価のための簡易質 問紙法「A型傾向判定表」J Type A Behavior Pattern 1:33-40, 1991.

10）加賀美年秀 : 痛風の合併症と死因, 予後. 日 本医師会雑誌 $111: 692-695,1994$.

11) Hall AP, Barry PE, et al : Epidemiology of gout and hyperuricemia: A long term population study. Am J Med 42 : 27-37, 1967.
12) Rao GN, Corson MA, Berk BC: Uric acid stimulates vascular smooth muscle cell proliferation by increasing platelet derived growth factor A chain expression.

J Biol Chem. 266 : 8604-8608, 1991.

13) Friedman M, Byers SO, Diamant J, et al. : Plasma catecholamine response of coronary-prone subjects (Type A) to a specific challange. Metabolism 24 : 205-210, 1975.

14) Fredrikson M, Blumenthal JA: Serum lipids, neuroendocrine and cardiovascular responses to stress in healthy Type A men. Biol Psychol 34 : 45-58, 1992.

15) Irvine J, Garner DM, Craig HM, et al : Prevalence of Type A behavior in untreated hypertensive individuals. Hypertension 18 : 72-78, 1991.

16) Faller J, Fox IH : Ethanol induced hyperuricemia: evidence for increased urate production by activation of adenine nucleotide turnover. N Engl J Med 307 : 1598-1602, 1982.

17) Yamanaka H, Kamatani N, Hakoda M, et al: Analysis of the genotypes for aldehyde dehydrogenase 2 in Japanese patients with primry gout. Adv Exp Med Biol 37 : 53-56, 1995.

18) Sims J, Boomsma DI, Carroll D, et al : Genetics of Type A behavior in two European countries : evidence for sibling interaction. Behav Genet 21 : 513-528, 1991.

19）前田 聰：タイプA行動パターン 心身医学 25 : 297-306, 1985.

20) Fukunishi I, Hattori, M; Hattori $H$, et al. : Japanese Type A behavior pattern is associated with "typus melancholicus" : a study from the sociocultural viewpoint. Int J Soc Psychiatry 38 : 251-256, 1992. 


\section{Prevalence of Type A behavior pattern among Japanese patients} with primary gout.

\author{
Hisáshi Yamanaka ${ }^{1)}$ \\ Wako Sendo \\ Shoichi Mizuno ${ }^{3)}$ \\ Atsuo Taniguchi ${ }^{1)}$ \\ Chihiro Terai ${ }^{1)}$ \\ Naoyuki Kamatani ${ }^{1)}$
}

Shin Totokawa ${ }^{1)}$

Masako Tomita ${ }^{2)}$

Momoko Yamaguchis)

Masayuki Hakoda ${ }^{1)}$

Sadao Kashiwazaki ${ }^{11}$
The prevalence of. Type A behavior pattern was investigated in 160 Japanese patients with primary gout using an established questionnaire.

Type A pattern was observed in $43.8 \%$ of the gouty group and $23.8 \%$ of the control group $(\mathrm{P}<0.01)$, and the average of the total Type A score was higher among gouty patient s compared to the control group $(\mathrm{P}<0.001)$. More goutypatients recognized themselves in busy and competitive life styles than control persons. In the control group, the serum uric acid concentration was correlated with a busy life, enthusiasm, impatience and ill-tempered characteristics. However, gouty patients also showed life style derangement such as heavyeating, heavy-drinking or rapid weight gain, and those with high scores in the Type A behavior pattern tended to have deranged life styles.

Based on these data, individuals with the Type A behavior pattern may be susceptible to hyperuricemia and gout by enhancing the phenotypical life style derangement. Type A is assumed to be the a coronary risk-factor.Thus, education to remodel the life style isnecessary for gouty patients with Type A toreduce the risk of coronary heart disease.

1) Institute of Rheumatology, Tokyo Women's Medical University

2) Central Health Institute of the East Japan Railway Company

3) Tokyo Metropolitan Institute of Gerontology

4) National Institute of Health and Nutrition 